\title{
ADAPTIVE CAPABILITY OF WAHATI SHEEP AND GOATS FLOCKS TO DESERT OASIS CONDITIONS IN THE NEW VALLEY OF EGYPT
}

\author{
A.M. Aboul Naga ${ }^{1}$, T. Abdel Khalek ${ }^{1}$, M. Hayder ${ }^{1}$, H. Hamdon ${ }^{2}$, G. Abozed ${ }^{1}$, T. Abdel Sabour ${ }^{1}$ \\ and M. Shafie ${ }^{1}$
}

1- Animal Production Research Institute, Agriculture Research Center, Cairo, 2- New Valley University, Faculty of Agriculture, El Kgarga, New Valley

Corresponding author: A.M. Aboul Naga, Animal production Research Institute, Dokki, Cairo Email: adelmaboulnaga@gmail.com

\section{Received: 28/3/2021 Accepted: 4/5/2021}

\section{SUMMARY}

The present work aimed at investigating adaptation of local Wahati sheep (Farafra) and Wahati goats in the breeders' flocks, to summer heat stress of desert oasis in the New Valley, Egypt. The study involved, 9 flocks from; El Dakhla, EL Kharga and El Farafra oasis. Total number of animals used in the study were 113 mature Wahati ewes and 100 mature Wahati does. Animals were exposed to summer heat stress (SHS) under solar radiation, from $12 \mathrm{pm}$ to $2 \mathrm{pm}$ in July 2018 and 2019. During exposure to heat of 101.8 to 103.8, indicating that animals were under severely heat stressed.

Exposing the animals to summer heat stress, significantly increased their physiological body parameters. Rectal temperature (RT) increased by $1.0^{\circ} \mathrm{C}$; where skin temperature (ST) increased by 9.5 and $9.0^{\circ} \mathrm{C}$, in only two species. These may be attributed to high intensity of solar radiation under desert oasis conditions. The major changes with SHS were in the respiratory rate (RR) as the main mechanism practiced by desert sheep and goats to get rid of the extra heat load through respiration. Accelerating $R R$, was not sufficient to cope with the severe heat stress load, so animals practiced deep breathing (increase gas volume); which was more recognizable in sheep than in goats. Species variation in response to heat stress can be attributed, to a great extent, to differences in their body size and coat thickness. The smaller the animal size, the lesser changes in their physiological body parameters with heat stress were noted.

\section{Keywords: Desert oasis, New valley, adaptation, physiological parameters, Wahati sheep, Wahati goats}

\section{INTRODUCTION}

The New Valley (NV) is the largest Governorate in Egypt, representing 44\% of the country total area. It is located in the south west of Egypt, extended from Libya borders in the west to Nile Valley in the east, and from Matrouh Governorate in the north, to Sudan border in the south, it contains three of the largest desert oases in Egypt: Dakhla, Kharga and Farafra (Fig.1). The NV has a unique environmental conditions of hot temperature in summer (ambient temperature in the shade can reach $50^{\circ} \mathrm{C}$ ), very cold nights in winter (below zero in some nights), scarce rainfall $(2-10 \mathrm{~mm} /$ annually) and high intensive solar radiation $\left(8.4 \mathrm{kwh} / \mathrm{m}^{2}\right)$, the highest value in Egypt (EMA, 2021\& Fig 1). Diurnal variation in ambient temperature varied widely between day and night, often exceeds $20^{\circ} \mathrm{C}$. Desert oases, being isolated for centuries, with severe environmental conditions, resulted in the modification of local Wahati sheep and goats characteristics to adapt to such harsh conditions (Elshazley and Youngs, 2019), mostly at the cost of their low productivity.

The prevailed agro-ecological conditions in the $\mathrm{NV}$ are; intensive agriculture system of more than a crop/year, with mixed crop-livestock production. Animal production depend on cut and carry of green fodder (Egyptian clover) in winter, Alfalfa and grazing crop residues fields in summer, in addition to supplement of concentrate feed. Rural community in the New Valley is livestock keepers, mainly sheep and goats, as the less susceptible animals to the prevailed harsh environmental stressors (Khalifa, et al., 2005). The severe climatic conditions are the major factors facing the development of local animal productivity in the hot dry desert oasis conditions. Ambient temperature may exceed the upper critical temperature of animals, beside scarcity of water and pasture, and intensive solar radiation.

Prevailed Wahati sheep (Farafra), have narrow medium size body, medium size head with straight profile. Most of the rams are dehorned, white fleece with brown head and small ears (Fig. 2). The fat tail has wide base ended by cylindrical part. The animals have white body with brown head or fully white body (Elhamamsy et al., 2018, Elshazley and Youngs, 2019 and Bashandy, et al., 2020). Wahati goats have small body with medium ears; both sexes are mostly horned, horns are relatively long spiraling out with upward inclination in males (Galal, et al., 2005, and El-Sayed, et al., 2016). Color is mostly black, but some lighter colors may found. The body is covered with long glossy hair.

The present work aimed to investigate adaptive capability of local Wahati sheep and goats at the breeders 'flocks to summer heat stress, under direct solar radiation in the desert oases of the New Valley. 


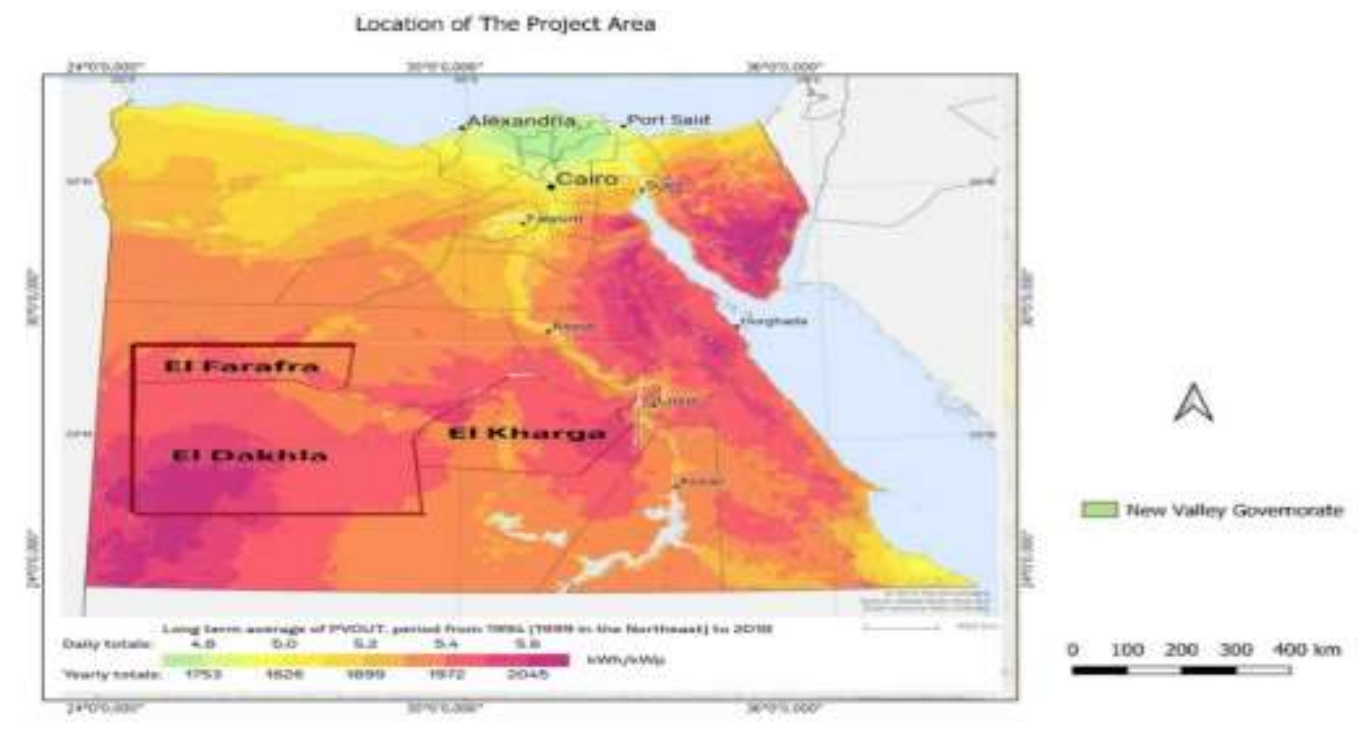

Fig. 1. Map of the study area (Kharga ,Dakhala and Frafra Oasis), (Source: Kosmopoulos et al. ( 2018). Solar Atlas of Egypt).
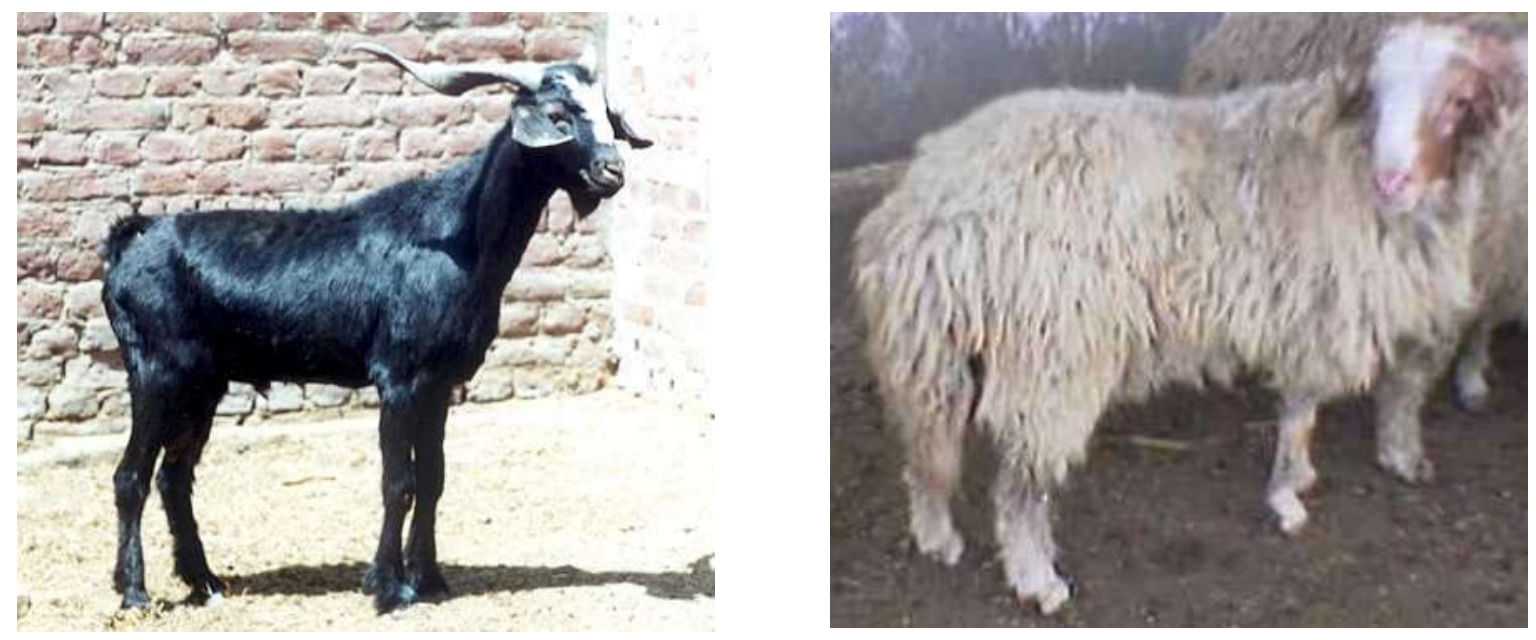

Fig. 2. Wahati goats and Wahati sheep (Farafra).

\section{MATERIALS AND METHODS}

\section{Experimental Animals:}

The study involved animals from nine breeders flocks (three flocks from each oasis) in the New Valley Governorate; Dakhla, Kharga and Farafra. Total number of animals covered by the study were
113 mature Wahati ewes and 100 mature Wahati does (Table1). Animals fed on green fodder (Egyptian clover) in winter. In summer they fed Alfalfa, graze crop residues fields, second grade dates, and concentrate feed supplement in summer.

Table 1. Number of Wahati sheep and Wahati goats enrolled

\begin{tabular}{lccccc}
\hline Item & \multicolumn{2}{c}{$\mathbf{2 0 1 8}$} & \multicolumn{2}{c}{$\mathbf{2 0 1 9}$} & Total \\
\cline { 2 - 5 } & sheep & goats & Sheep & goats & \\
\hline Location: & & & & & \\
El Dakhla oases & 32 & 16 & 10 & 16 & 74 \\
El Kharga oases & 18 & 18 & 15 & 13 & 64 \\
El oases & 20 & 20 & 18 & 17 & 75 \\
Total & 70 & 54 & 43 & 46 & 213 \\
\hline
\end{tabular}


During the study period (2018 - 2019), ewes and does from the breeder's flocks were exposed to direct solar radiation from $12 \mathrm{pm}$ to $2 \mathrm{pm}$ in July. Dry bulb temperature (TDB), and relative humidity (RH) were measured at rest $(7 \mathrm{am})$, and at exposure at treatment day, using dry thermometer and hygrometer. THI was calculated according to Hahn and Mader (1997): $\mathrm{THI}=((\mathrm{TDB} * 1.8)+32)-((0.55 *(\mathrm{RH} / 100)) *(\mathrm{TDB} * 1.8)$
+32)-58. It averaged 101.8 and 103.8 in 2018 and 2019, respectively (Table 2), indicating that the animals were under severe heat stress, with variation between different oases. Metrological parameters, showed hotter and drier conditions in the south Kharga oasis; resulted in higher THI of 108.9 and 110.0, in 2018 and 2019, respectively.

Table 2. Meteorological information and THI

\begin{tabular}{lcccccc}
\hline Year & \multicolumn{2}{c}{ AT $^{*}$} & \multicolumn{2}{c}{ RH } & \multicolumn{2}{c}{ THI } \\
\hline 2019 & At rest & At exposure & At rest & At exposure & At rest & At exposure \\
El Kharga & 31.5 & 47.5 & 38.0 & 26.0 & 82.3 & 108.9 \\
El Dakhla & 27.0 & 45.7 & 58.0 & 33.3 & 73.7 & 103.9 \\
El Farafra & 26.7 & 44.7 & 26.3 & 16.3 & 90.3 & 107.6 \\
Overall & 27.7 & 45.8 & 42.7 & 25.2 & 80.9 & 106.5 \\
2020 & $(25-38)$ & $(42-49)$ & $(24-70)$ & $(14-40)$ & $(69.7-94.8)$ & $(100.9-112.1)$ \\
El Kharga & 33.0 & 48.0 & 40.0 & 25.5 & 84.1 & 110.0 \\
El Dakhla & 32.0 & 43.5 & 58.0 & 47.0 & 79.5 & 96.9 \\
El Farafra & 32.0 & 43.5 & 57.0 & 41.5 & 79.7 & 98.4 \\
Overall & 32.3 & 45.0 & 51.7 & 38.0 & 81.1 & 101.8 \\
& $(30-35)$ & $(42-50)$ & $(40-60)$ & $(22-58)$ & $(77.1-86.9)$ & $(91.8-114.3)$ \\
\hline
\end{tabular}

*AT: Ambient Temperature, RH: Relative Humidity, THI: Temperature Humidity Index

Physiological body parameters were measured, at rest (7am), and after exposure to summer heat stress (SHS) under direct solar radiation $(2 \mathrm{pm})$. The thermal parameters were: rectal temperature $\left(\mathrm{RT},{ }^{\circ} \mathrm{C}\right)$ measured by clinical thermometer; skin temperature $\left(\mathrm{ST},{ }^{\circ} \mathrm{C}\right)$, and ear temperature $\left(\mathrm{ET},{ }^{\circ} \mathrm{C}\right)$, measured by infrared thermometer (Menolita, Japan). The respiratory parameters were: respiration rate (RR, res. /min), exhaled gas volume ( $\mathrm{GV}, \mathrm{L} / \mathrm{min})$ measured by dry gas meter (Harvard, UK) Animals were weighed before exposure to heat stress.

\section{Statistical analysis:}

Statistical analysis of variance was performed on the studied physiological body parameters, by SAS (2009), for the fixed effects of: location, year, body weight groups, and animal as random factor. Principle Component Analysis (PCA) was carried out using SPSS (2008) to investigate animal variation in response to SHS, and to identify high and low tolerant animals according to changes in their physiological parameters. Two components were retained for PCA that explained most of total variance $(62 \%)$; thermal parameters (RT and ST) as component 1 and respiratory parameters (RR and $\mathrm{GV}$ ) as component 2 .

The model used for the statistical analysis was;

$\mathrm{Y}_{\mathrm{ijkl}}=\mu+\mathrm{S}_{\mathrm{i}}+\mathrm{L}_{\mathrm{j}}+\mathrm{BW}_{\mathrm{k}}+\mathrm{e}_{\mathrm{ijkl}}$ where,

$\mathrm{Y}_{\mathrm{i} i \mathrm{kl}}$ is the value of the studied parameter (RT, ST, RR and GV),

$\mu$ is the overall mean,

$S_{i}$ is the fixed effect of $i^{\text {th }}$ studied species, $i=1$ to 2 ( $1=$ sheep and 2 = goats),
$L_{i}$ is the fixed effect of $j^{\text {th }}$ location, $j=1$ to 3 (1=Dakhla, 2=Kharga and 3= Farafra),

$\mathrm{BW}_{\mathrm{k}}$ is the fixed effect of $\mathrm{k}^{\text {th }}$ body weight groups and, $\mathrm{k}=1$ to $8(1=10-15,2=16-20 \ldots$ and $8>45 \mathrm{~kg})$, and $\mathrm{e}_{\mathrm{ijkl}}$ is the random error assumed NID $\left(0, \sigma_{\epsilon}^{2}\right)$

Duncan test was used to compare means within the same category.

\section{RESULTS AND DISCUSSION}

Exposing local Wahati sheep and goats flocks to summer heat stress under solar radiation (SHS), significantly raised their physiological body parameters (Table 3). Rectal temperature increased by about $1.0 \pm 0.05^{\circ} \mathrm{Cfor}$ both sheep and goats, when exposed to summer heat stress. Skin temperature increased sharply by $9.5 \pm 0.36$ and $9.0 \pm 0.38{ }^{\circ} \mathrm{C}$, for Wahati sheep and goats, respectively. Changes in ST come up to $20^{\circ} \mathrm{C}$ for some animals from both species. These can be attributed to the very intensive solar radiation prevailed (Fig.1) on increasing the vasodilation of skin capillary bed in enhancing blood flow to the skin, to facilitate heat transfer to the surroundings, as explained by Sejian, et al. (2018). There were also large changes in ET for both species, 8.9 and $8.4^{\circ} \mathrm{C}$ for Wahati sheep and goats, respectively (ranged from 0.3 to 24.5 in sheep and from 0.9 to 22.8 in goats).

The major changes detected in the studied physiological body parameters with exposure to SHS, were in the RR (179 and $151 \%$ for sheep and goats, respectively), which is considered to be the main mechanism practiced by sheep and goats to get rid of the extra heat load. Panting is the major evaporation heat loss mechanism for sheep and goats species 
(Robertshaw, 2006). Changes in RR is be recommended as main parameter to assess tolerance of desert sheep and goats to heat stress under extensive conditions. Davis, et al. (2003) stated that RR proves to be the most accessible and easiest technique for evaluating the impact of heat stress on farm animals under stress conditions. When accelerating respiration rate is not enough for the animal to cope with the severe heat stress, they practice deep breathing (increase their GV) to avoid alkalosis (Hales, 1969). This was more recognizable more with Wahati sheep than with Wahati goats. Similar species variation in the respiration mechanism to cope with heat stress, was reported by Aboul Naga, et al. (2011), for desert Barki sheep and goats. Barki sheep practiced more deep breathing to cope with the needed energy for physical exercise under heat stress, than Barki Goats. Mehaba, et al. (2021) reported significant increase in RR and GV in heat stressed dairy ewes, compared to that under thermo-neutral conditions.

Table 3. Physiological body parameters of Wahati sheep and Wahati goats in the New Valley

\begin{tabular}{lccc}
\hline & Morning $(7 \mathrm{am})$ & Noon $(2 \mathrm{pm})$ & Changes \\
& LSM \pm SE & LSM \pm SE & \\
\hline Wahati sheep $(\mathrm{N}=113)$ & & & $1.0 \pm 0.05$ \\
$\mathrm{RT}\left({ }^{\circ} \mathrm{C}\right)$ & $39.1 \mathrm{~b} * \pm 0.05$ & $40.1 \mathrm{a} \pm 0.05$ & $(0.0-3.4)$ \\
& $(38.0-40.7)$ & $(38.9-41.7)$ & $9.5 \pm 0.36$ \\
$\mathrm{ST}\left({ }^{\circ} \mathrm{C}\right)$ & $35.0 \mathrm{~b} \pm 0.17$ & $44.5 \mathrm{a} \pm 0.33$ & $(1.0-20.8)$ \\
& $(30.1-38.3)$ & $(36.8-54.3)$ & $9.0 \pm 0.73$ \\
$\mathrm{ET}\left({ }^{\circ} \mathrm{C}\right)^{*}$ & $33.3 \mathrm{~b} \pm 0.38$ & $42.3 \mathrm{a} \pm 0.53$ & $(0.3-24.5)$ \\
& $(27.6-37.9)$ & $(36.5-53.0)$ & $49.7 \pm 2.29$ \\
$\mathrm{RR}(/ \mathrm{min})$ & $27.7 \mathrm{~b} \pm 0.55$ & $77.4 \mathrm{a} \pm 2.19$ & $(8.0-120.0)$ \\
& $(20.0-45.0)$ & $(40.0-140.0)$ & $2.2 \pm 0.12$ \\
$\mathrm{GV}(\mathrm{l} / \mathrm{min})$ & $2.5 \mathrm{~b} \pm 0.05$ & $4.6 \mathrm{a} \pm 0.11$ & $(0.0-5.8)$ \\
Wahati goats $(\mathrm{N}=100)$ & $(1.4-4.0)$ & $(2.4-8.2)$ & $1.1 \pm 0.06$ \\
$\mathrm{RT}\left({ }^{\circ} \mathrm{C}\right)$ & $38.9 \mathrm{~b} \pm 0.04$ & & $(0.0-2.6)$ \\
& $(38.0-40.5)$ & $40.0 \mathrm{a} \pm 0.06$ & $9.0 \pm 0.38$ \\
$\mathrm{ST}\left({ }^{\circ} \mathrm{C}\right)$ & $35.5 \mathrm{~b} \pm 0.20$ & $(38.5-41.3)$ & $(2.3-20.7)$ \\
& $(31.2-39.4)$ & $44.4 \mathrm{a} \pm 0.39$ & $8.6 \pm 1.01$ \\
$\mathrm{ET}\left({ }^{\circ} \mathrm{C}\right)^{*}$ & $33.5 \mathrm{~b} \pm 0.51$ & $(38.5-58.9)$ & $(0.9-22.8)$ \\
$\mathrm{RR}(/ \mathrm{min})$ & $(27.2-36.8)$ & $42.2 \mathrm{a} \pm 0.67$ & $34.8 \pm 2.06$ \\
$\mathrm{GV}(\mathrm{l} / \mathrm{min})$ & $23.1 \mathrm{~b} \pm 0.43$ & $(36.4-51.0)$ & $(4.0-100.0)$ \\
& $(17.0-36.0)$ & $57.9 \mathrm{a} \pm 2.04$ & $1.8 \pm 0.10$ \\
& $2.1 \mathrm{~b} \pm 0.05$ & $(30.0-120.0)$ & $(0.0-5.2)$ \\
\hline
\end{tabular}

*Within each parameter, estimates followed by the same letter don't differ significantly from each other at $\mathrm{P}>5 \%$

RT: Rectal Temperature; ST: Skin Temperature; ET: Ear Temperature; RR: Respiration Rate; GV: Gas Volume.

Analysis of variance of changes in the physiological body parameters with SHS, showed highly significant variation $(\mathrm{P} \geq 0.01)$ due to species, location, treatment, and body weight on RR and GV (Table 4). Data confirmed that respiration rate and type of panting (shallow or deep) were the main mechanism used by desert Wahati sheep and goats to tolerate severe heat stress. Respiratory and cutaneous cooling mechanism, are involved in dissipation of the extra heat load by vaporizing more moisture to the surroundings (Berman, 2006). With the extension of the three oases over large area of land, variation due to location (oasis) were also highly significant $(\mathrm{P} \geq 0.01)$, except for RT. Elkharga oasis, as the far south oasis, showed higher THI (ranged from 108114), and ambient temperature from $42-50^{\circ} \mathrm{C}$, with lower precipitation.

Table 4. ANOVA for changes in physiological body parameters of Wahati sheep and goats with SHS

\begin{tabular}{|c|c|c|c|c|c|c|}
\hline \multirow{2}{*}{$\begin{array}{l}\text { Source of } \\
\text { variation }\end{array}$} & \multirow{2}{*}{ df } & \multicolumn{5}{|c|}{ MS } \\
\hline & & RT & ST & ET & RR & GV \\
\hline Specie & 1 & 0.92 & 21.8 & 1.9 & $11703 * *$ & $8.1 * *$ \\
\hline Location & 2 & 0.74 & $105.7 * *$ & $1039 * *$ & $9587 * *$ & $20.7 * *$ \\
\hline Body weight & 7 & $0.72 *$ & 9.52 & 25.1 & $2001 * *$ & $3.0 * *$ \\
\hline Residual & 202 & 0.29 & 10.2 & 17.2 & 370.9 & 1.1 \\
\hline
\end{tabular}

RT: Rectal Temperature; ST: Skin Temperature; ET: Ear Temperature; RR: Respiration Rate; GV: Gas Volume

Significant species variation in the changes of the physiological body parameters (mainly RR and GV) can be attributed, to a great extent, to differences in their body size. Mature Wahati ewes weighed in average $35.1 \mathrm{~kg}$ vs. 20.1 for Wahati does. Both breeds are considered small size breeds, within their 
species ranges. They have wide variation in their body weight (Galal, et al., 2005). Generally, the smaller in size animals, the lesser changes in their physiological body parameters with SHS (Fig 3).

The PCA distribution of Wahati sheep (Fig.4, left), Wahati goats (Fig.4, right), showed animals with the least changes in their physiological parameters (high tolerant animals) from both Wahati sheep and goats, are located in the $3^{\text {rd }}$ quarter (left

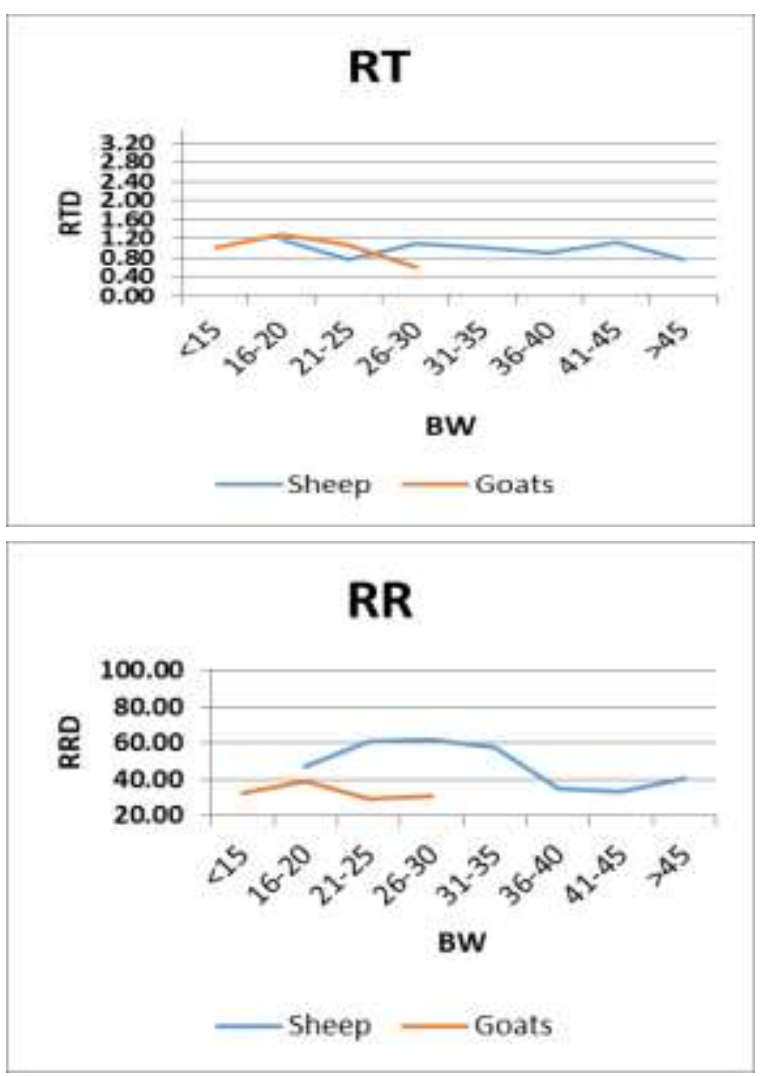

down). While, low tolerant animals didn't show clear trend in this regard, and scattered all over the four quarters. The studied physiological parameters identified well the high tolerance of Wahati sheep and goats, especially RR and GV parameters, but not for the low tolerant animals. Further physiological and genetic parameters are needed for the identification of low tolerant Wahati sheep and goats.

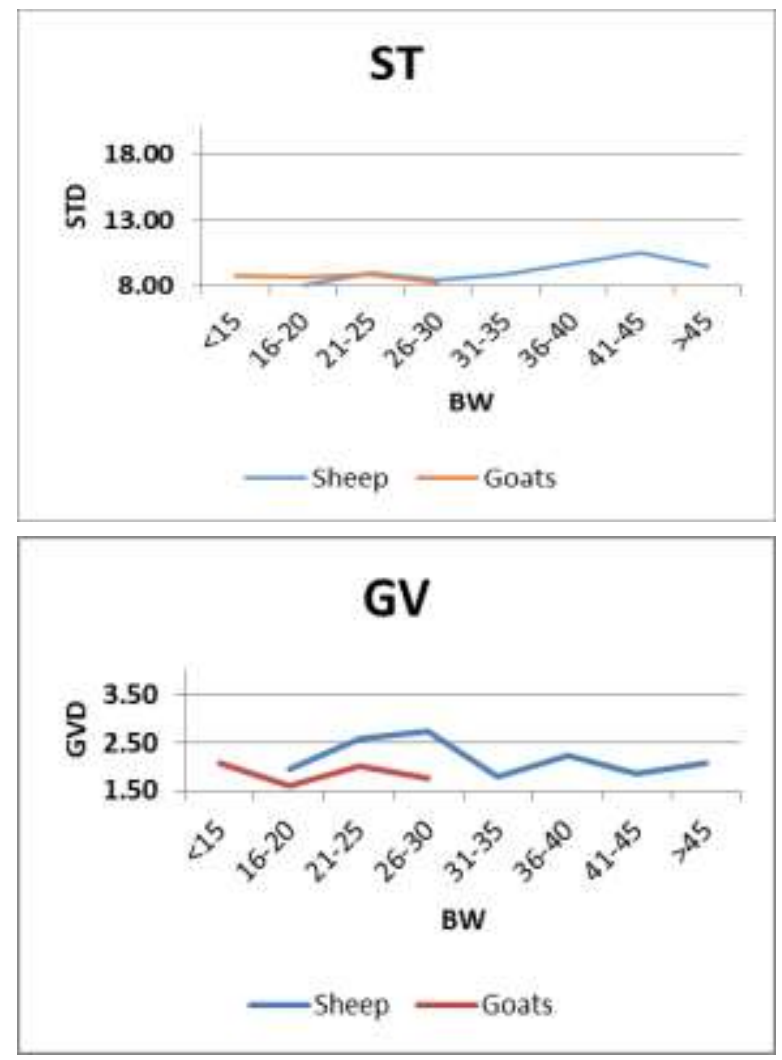

Fig (3) changes in physiological parameters of Wahati sheep and goats with their body weights.

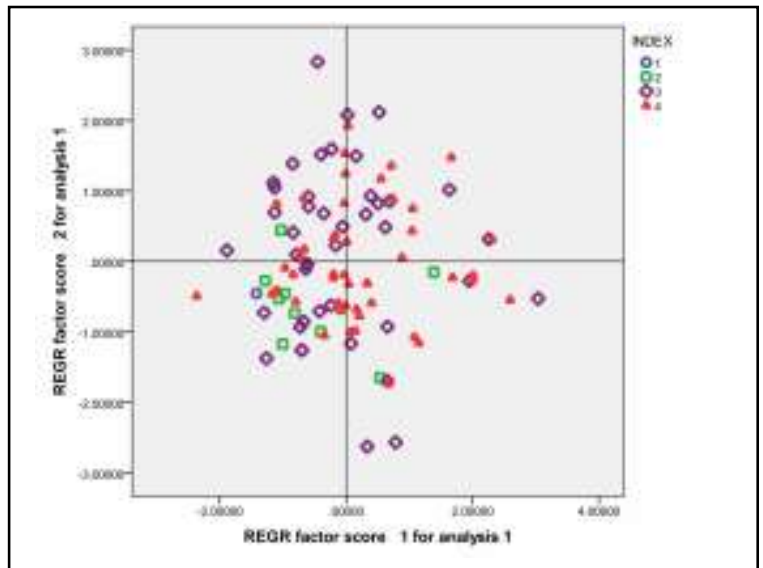

Sheep

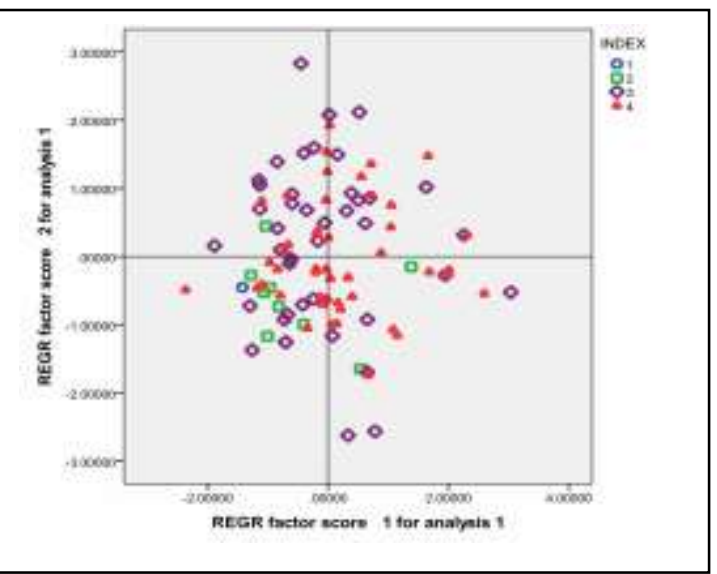

Goats

Fig. 4. PCA distribution of Wahati sheep and goats according to the PCA.

\section{CONCLUSIONS}

Main changes in the physiological body parameters of Wahati sheep and goats, with summer heat stress, were significant increase in RR and GV, which were more profound in sheep than in goats. The intensive solar radiation increased sharply their
ST and ET. The prevailed harsh environment, resulted in the modification of Wahati sheep and goats 'characteristics to tolerate, produce and reproduce successfully under the hot dry desert oasis conditions, at the cost of low growth rate, lower fecundity and high losses in young animals (Abdel 
Sabour, 2021). Low body mass and metabolic requirement of animals are regarded as assets to minimize their maintenance and water requirements in areas where water and feed resources are limited by quantity and quality (Silanikove, 2000).Management practiced by the breeders in the $\mathrm{NV}$, to cope with the severe environmental conditions of the desert oasis, is merely shedding the animals at noon in summer, and confine them in winter nights (Abdel Sabour, 2021).

The present finding of high capability of Wahati sheep and goats to stand the very harsh conditions of the desert oasis, make them genuine animals in tolerating summer heat stress under intensive solar radiation. More investigations on their phenotypic and genetic characteristics in relation with their adaptive capacity to such harsh conditions are needed. Furthermore, wide intra-species variation, encourage the practice of intensive selection within their indigenous populations, for genetically adapted animals to severe desert climate conditions.

\section{REFERENCES}

Abdel Sabour, T., 2021. Assessment of Breeding and Management Practices for Resilient and Productive Sheep and Goats Systems, Based on Locally Adapted Breeds, at Different AgroEcological Zones of Egypt, PhD Thesis, AinShams University ,Cairo (personal communications)

Aboul-Naga, A.M., H.H. Khalifa, A.R. El-beltagy, T.M.M. Abdel-Khalek, M.H. Elshafie, M.M. Anwar, B. Rischkowsky, 2011. Tolerance to abiotic stresses in Egyptian Barki desert sheep and goats raised under hot-dry conditions: Individual variations. $10^{\text {th }}$ International Conference on Development of Dry lands, Meeting the Challenge of Sustainable Development in Dry lands under Changing Climate ,12 December 2010, Cairo, Egypt. Pp. 445-459.

Bashandy, T., A. Hussein, M. Solma, A. Kassab, and H. Hamdon, 2020. Molecular evaluation of three populations of Farafra sheep in comparison to Ossimi and Rahmani sheep breeds. ACTA Univ. Agri. EtSilv. Mend. Brun. Vol. 68. 929936.

Berman, A., 2006. Extending the potential of evaporative cooling for heat stress relief. Journal of Dairy Science,89:3817-3825.

Davis, M.S., T.L. Mader, S.M. Holt, and A.M. Parkhurst, 2003. Strategies to reduce feedlot cattle heat stress: effects on tympanic temperature. J. Anim. Sci., 81: 649-661.

El-Hamamsy, S.M., M.A. El-Sayed, A.A. El Badawy and Doaa F. Teleb, 2018. Characterization of some Egyptian Sheep Populations Using Microsatellite and Protein Markers. J. Agric. Chem. and Biotechn., Mansoura Univ. Vol. 9 (8): $181-188$.

Elsayed, M.A., A. Al-Deoudy and A.A. El Badawy, 2016. Microstalite Markers polymorphism between two Egyptian goat populations. Egypt J. Genet. Cytol. , Vol:45,89-103.

Elshazly, A.Z. and C.R. Youngs, 2019. Feasibility of utilizing advanced reproductive technologies for sheep breeding in Egypt. Part 1.Genetic and nutritional resources .Egypt. J. Sheep and Goats ol.14,No1:39-52

EMA, 2021. Egyptian Metrological Authority, Ministry of Civil Aviation , Cairo ,Report 611

Galal, E.S., Ferial Abdel-Rasoul, M.R. Anous, I.M. Sahaat, 2005. On station characterization of small ruminant breeds in Egypt. In: Characterization of Small Ruminant Breeds in West Asia and North Africa, 2: 141-193 Luis Iniguez (Ed.) ICARDA, Aleppo, Syria

Hahn, G.L., and T.L. Mader, 1997. Heat waves in relation to thermo-regulation, feeding behavior and mortality of feedlot cattle. Proc. 5th Int. Livest. Environ. Symp. Amer. Soc. Agric. Eng., St. Joseph, MI, pp. 563-57 .

Hales, J.R.S., 1969. Changes in respiratory activity and body temperature of the severely heatstressed ox and sheep .Comparative Biochemistry and Physiology ,Vol:31,6 :975-985.

Khalifa, H.H., T. Shalaby, T.M. Abdel Khalek, 2005. An approach to develop a bio meteorological thermal discomfort index for sheep and goats under Egyptian conditions. Proceeding of the 17th International Congress of Biometeorology, Garmisch, Germany, 5-9 September, 2005, Edit., Deutscher, Wetterdienst, Kaiserleistr, 29-35, 63067 Offenbach am Main, Germany, pp. 118-12

Kosmopoulos P., S. Kazadzis, H. El-Askary, 2018. The Solar Atlas of Egypt. http://www.nrea.gov.eg/Content/files/SOLAR\%2 0ATLAS\%202018\%20digital1.pdf

Mehaba, N., W. Coloma-Garcia, X. Such, G. Caja, and Salama Ahmed, 2021. Heat stress affects some physiological and productive variables and alters metabolism in dairy ewes .Journal of Dairy Science ,104(1):1099-1110

SAS, 2009. SAS User's Guide: Statistics. SAS Inst. Inc., Cary, NC.,US

Sejian ,V., R.R. Bhatta, J.B. Gaughan, F.R. Dunshea, and N. Laccetera, 2018. Review Adaptation of animals to heat stress .Animal 12(S2):431-444

Silanikove, N., 2000. The Physiological Basis of Adaptation in Goats to Harsh Environments. Small Rum. Res., 35, 181-193.

SPSS, 2008. Statistical Package for the Social Sciences, Release 17.0.0, August 23, 200

Robertshaw, D., 2006. Mechanism for the control of respiratory evaporative heat loss in panting animals .J. Appl. Physiol. 101:664-668. 


\section{القدرة التكيفية لقطعان الأغنام والماعز الواحاتى لظروف الواحات الصحراوية بالوادى الجديد بمصر}

عادل محمودأبو النجا'، ططارق عبدالخالق'، محم حيدر'،حاتم حمدون'،جمال أبوزيد'، طه عبدالصبور '، محم حسن الثافعي' اـمعهد بحوث الإنتاج الحيواني، مركز البحوث الزراعية، القاهرة، ؟ - جامعة الوادى الجديد، محافظة الوادي الجديد، الخارجة

يمهذف العمل الحالي إلى دراسة تكيف الأغنام الواحاتي (تسمى أيضًا الفرافرة) والماعز الواحاتي في قطعان المربين،مع الإجهاد الحراري

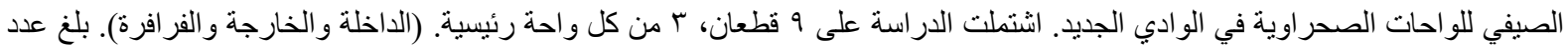

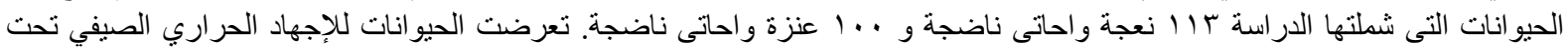

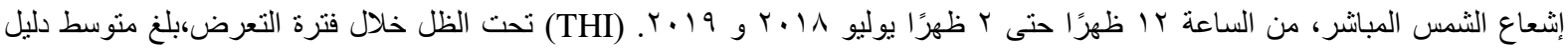

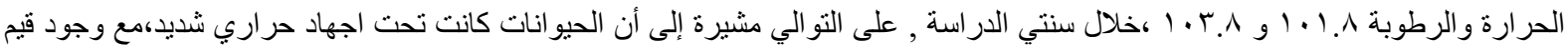

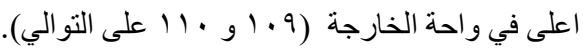

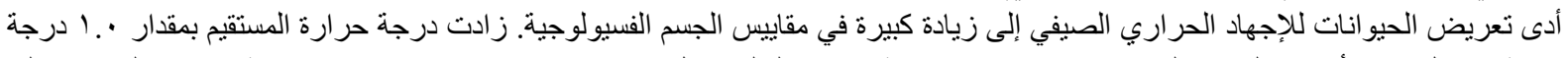

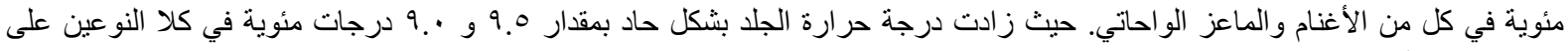

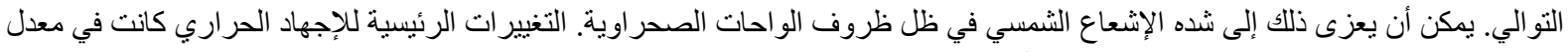

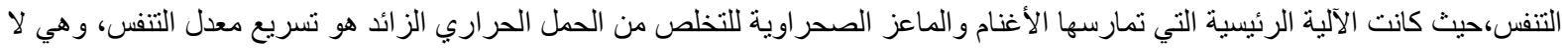

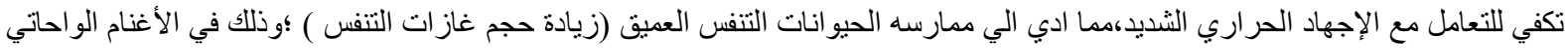

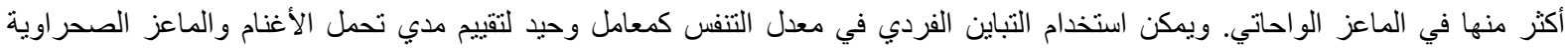

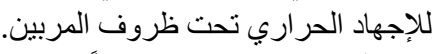

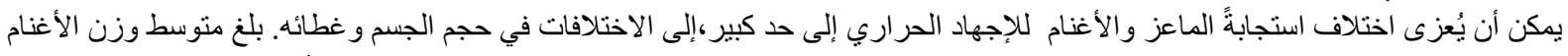

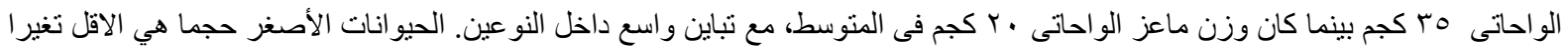
في معايير ها الفسيولوجية مع الإجهاد الحراري. 